\title{
Is agriculture eroding civilization's foundation?
}

\author{
David R. Montgomery, Quaternary Research Center \\ and Department of Earth and Space Sciences, University \\ of Washington, Seattle, Washington 98195-1310, USA
}

\begin{abstract}
Recent compilations of data from around the world show that soil erosion under conventional agriculture exceeds both rates of soil production and geological erosion rates by from several times to several orders of magnitude. Consequently, modern agriculture - and therefore global society-faces a fundamental question over the upcoming centuries. Can an agricultural system capable of feeding a growing population safeguard both soil fertility and the soil itself? Although the experiences of past societies provide ample historical basis for concern about the long-term prospects for soil conservation, data compiled in recent studies indicate that no-till farming could reduce erosion to levels close to soil production rates. Similarly, organic farming methods have been shown to be capable of preserving-and in the case of degraded soils, improving-soil fertility. Consequently, agricultural production need not necessarily come at the expense of either soil fertility or the soil, even if recent proposals to rely on conventionally grown corn for biofuels exemplify how short-term social and economic trade-offs can deprioritize soil conservation. Like the issues of climate change and loss of biodiversity, ongoing global degradation and loss of soil present fundamental social challenges in which the slow pace of environmental change counterintuitively makes solutions all the more difficult to adopt.
\end{abstract}

They're making more people every day but they ain't makin' any more dirt.-Will Rogers

\section{INTRODUCTION}

Public concern over the future of civilization and issues of sustainability in general tends to focus on global warming, loss of biodiversity, and the end of the fossil-fuel era. Far less societal concern has been focused on how dramatically conventional agriculture has increased soil erosion around the world, however, or on the role of soil degradation and loss in the history and fate of civilizations. With global agricultural soil erosion outpacing soil production by a wide margin (Wilkinson and McElroy, 2007; Montgomery, 2007b), modern conventional agriculture is literally mining soil to produce food (Fig. 1) - and yet, feeding humanity fundamentally depends on fertile soil. Unless this deceptively simple problem is solved, soil loss will become a key issue facing society over the next several centuries, in a process like that recognized as contributing to the decline of ancient societies (e.g., Montgomery, 2007a). Even a casual reading of history shows that under the right circumstances, climatic extremes, political turmoil, and/or resource

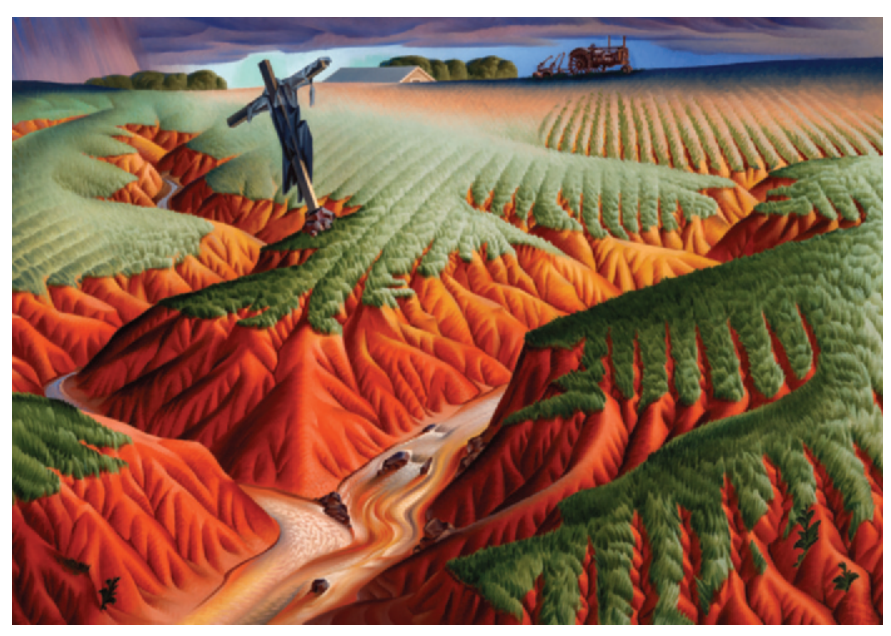

Figure 1. Crucified Land, by Alexandre Hogue (1898-1994). Oil on canvas, 1939. Courtesy of Gilcrease Museum, Tulsa, Oklahoma.

abuse can bring down a society, and in the upcoming century, we face the potential convergence of all three as shifting climate patterns and depleted oil supplies collide with accelerated soil erosion and the resulting loss of cropland (Brink et al., 1977; Larson et al., 1983; Ruttan, 1999).

Soil erosion represents just a single aspect of agricultural sustainability because soil productivity involves nutrient budgets, not just soil loss. Ecologically productive soils, those with more soil microorganisms and organic matter, can support greater plant growth. Numerous studies have shown how conventional tillage reduces soil organic matter (Lal, 2007) and thereby reduces biological activity that supports soil fertility. In addition, soils that thin due to rapid erosion have reduced weathering time that may limit the availability of key plant nutrients, leading to reduced soil fertility. And it has long been recognized that sustained cropping without appropriate crop rotation can deplete soil nutrients and that chemical fertilizers can greatly enhance the productivity of degraded soils. So even though the issue of sustainable soil erosion may be appropriately gauged by soil production rates, the overall health and fertility of the soil further depends on soil nutrient and organic matter contents. An agricultural soil need not be entirely eroded away to preclude economical farming.

Farmers around the world plow to prepare the seedbed for planting, to mix crop residues, manure, and fertilizers into the soil, and to dry and warm the soil in spring. Plowing leaves soils bare and vulnerable to erosion, especially on modern mechanized farms, leading to net soil loss and degradation (Dale and Carter, 1955). Each pass of the plow also pushes soil downslope: The straight, angled blade of a conventional plow lifts and turns soil over, pushing it aside and moving it downhill 
little by little. So even plowing along topographic contours accelerates soil erosion-all the more so on steeper slopes. This is not an issue in the flat-bottomed floodplains along river valleys, where plowing shifts soil back and forth, but on the intervening slopes, including the gently inclined land of the plains, the soil thins over time, and runoff across bare fields carries it to streams and rivers. How long it takes to deplete the soil depends not only on how fast plowing pushes soil downhill and runoff carries soil away but also on how rapidly the underlying rocks break down to replace eroded soil.

In the 1970s and 1980s, recognition that soil erosion was outpacing soil production led to warnings that society could run out of soil before oil (Brown, 1981). While such concerns now appear rather overstated, soil erosion under conventional plow-based agriculture proceeds slowly enough for a farmer to ignore in his or her lifetime (Osterman and Hicks, 1988), but fast enough to wear away the fertile topsoil capable of sustaining high crop yields in just a few generations (Dale and Carter, 1955; Hillel, 1991; Montgomery, 2007a).

\section{RATES OF SOIL LOSS}

Recent studies confirm that agricultural soil erosion substantially outpaces soil production under now-conventional agricultural practices around the world. Specifically, Wilkinson and McElroy (2007) reported that an average erosion rate of 0.6 $\mathrm{mm} \mathrm{yr}^{-1}$ from modern farmlands greatly exceeds the estimated average erosion rate of $0.016 \mathrm{~mm} \mathrm{yr}^{-1}$ over the past $500 \mathrm{~m} . \mathrm{y}$. based on the preserved volumes of sedimentary rocks. Similarly, Montgomery (2007b) compiled data from a wide range of contexts around the world to compare soil erosion rates under conventional, plow-based agriculture with long-term geologic rates and found that the distributions differed by one to two orders of magnitude (Fig. 2).

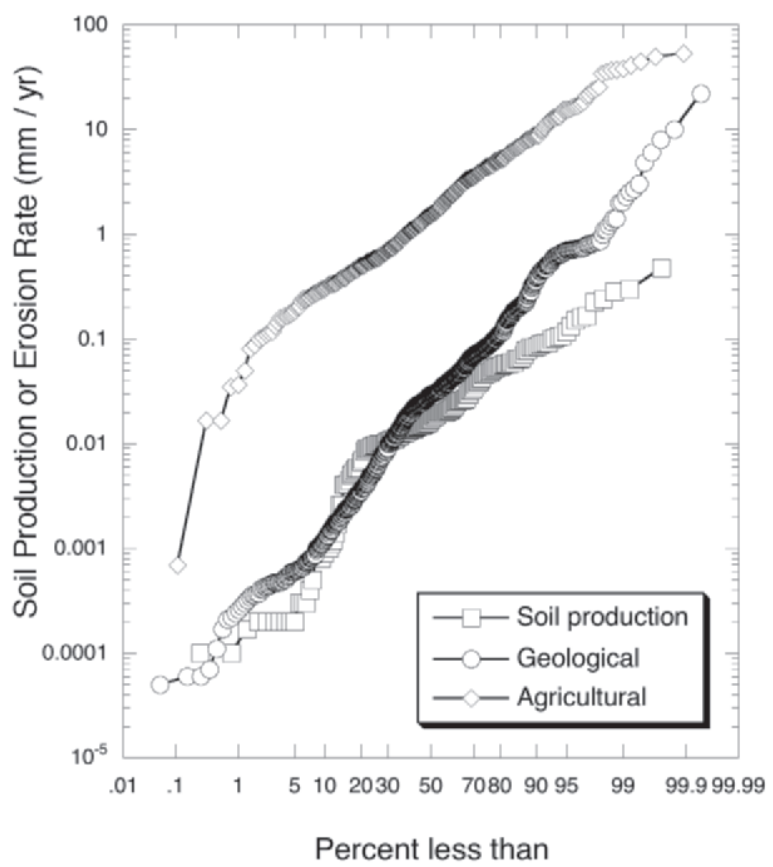

Figure 2. Percentile plot of agricultural erosion rates and geological erosion rates, as well as soil production rates (see Montgomery, 2007b, for compiled data and sources).
But how representative are such comparisons, given that they involve such disparate spatial and temporal scales? The most recent compilation of data from studies that directly assess soil erosion rates from agricultural land use shows increases of several to a thousand times above pre-agricultural rates (Fig. 3). Some estimates hold that nearly a third of the world's potentially farmable land already has been lost to erosion since the dawn of agriculture-and much of it in the past forty years. In 1990, the Global Assessment of Soil Degradation found that human-induced soil erosion and salinization had already affected almost two billion hectares of agricultural land (Bridges and Oldeman, 1999). Ongoing soil degradation and loss present a global ecological crisis that, although less dramatic than climate change or a comet impact, can prove catastrophic nonetheless, given time.

\section{RATES OF SOIL PRODUCTION}

Hardly any data on rates of soil production were available in the 1950s when the Soil Conservation Service began developing the concept of soil loss tolerance values ( $T$ values) to define "tolerable" rates of soil erosion from agricultural land. In practice, $T$ values were set by what was attainable using conventional farming equipment without undue economic impact on farmers, prompting concerns that "acceptable" $T$ values would allow erosion at a pace far faster than soil rebuilds.

Over the past several decades, direct quantification of soil production rates became possible through measurements of the abundance of certain isotopes (particularly ${ }^{10} \mathrm{Be}$ and ${ }^{26} \mathrm{Al}$ ) in and at the base of soil profiles. Produced at a known rate when cosmogenic rays bombard quartz grains, their concentrations can be used to calculate rates of soil production. Pioneering applications of this technique to temperate regions in coastal California and southeastern Australia (Heimsath et al.,

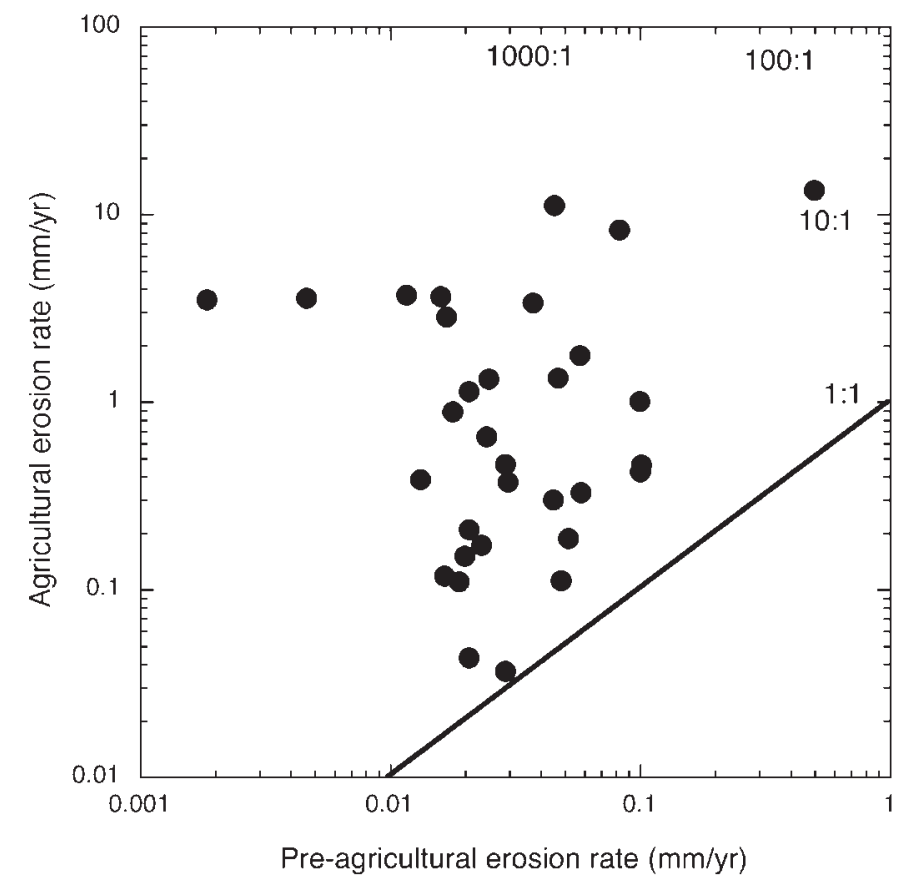

Figure 3. Pre-agricultural erosion rates versus erosion rates under conventional agriculture on comparable terrain (see Montgomery, 2007b, for compiled data and sources). 
1997, 2000) confirmed nineteenth-century hypotheses that a thick blanket of soil would protect the bedrock from weathering, whereas a thin soil accelerates soil formation by exposing the underlying rock. So, as soil thickens, the rate of soil formation slows, leading to an equilibrium soil depth that locally reflects the particular balance between soil production and erosion. Soil production rates likely vary closely with long-term geological erosion rates, and estimates of average global soil production range from 0.058 to $0.083 \mathrm{~mm} / \mathrm{yr}$ (Wakatsuki and Rasyidin, 1992; Troeh et al., 1999).

\section{ANCIENT SOIL LOSS}

Throughout history, societies grew and could prosper as long as the soil remained productive or there was new land to plow and declined when neither remained true. Recent archaeological studies in Greece (Pope and van Andel, 1984; van Andel et al., 1990; Runnels, 1995), the South Pacific islands (Kirch, 1996, 1997), and the Mayan homeland in Central America (Beach, 1998; Beach et al., 2006), among other regions, point to soil erosion as a significant factor in the decline of ancient societies. Although the reasons behind the rise and fall of any particular civilization are complex (Tainter, 2006), and soil erosion and degradation alone did not trigger the outright collapse of prior civilizations, their soil budgets set the stage upon which economics, climate extremes, and warfare influenced their fate. In a broad sense, the history of many civilizations follows a common story line (Montgomery, 2007a) in which agriculture in fertile valley bottoms allowed populations to grow to the point that they came to rely on farming sloping land, and geologically rapid erosion of hillslope soils followed when sustained tillage continuously exposed bare soil to rainfall and runoff. Once no new land was available, nutrient depletion or soil loss during subsequent centuries encouraged increasingly intensive farming, which promoted further soil loss. While some societies developed agricultural practices that conserved soil, and even improved soil quality, more often soil loss and degradation eventually translated into inadequate agricultural capacity to support a burgeoning population, triggering societal decline, territorial expansion, or agricultural innovations.

\section{POTENTIAL TO FURTHER INCREASE AGRICULTURAL PRODUCTIVITY}

Feeding the doubled human population anticipated later this century without further increasing crop yields would require doubling the roughly one and a half billion hectares presently under cultivation. Realistically, the only remaining vast tracts of virgin land that could be brought into production are tropical forests and subtropical grasslands-like the Amazon and the Sahel (Tilman et al., 2001)—where experience shows that conventional farming will produce an initial return until the land quickly becomes degraded and then abandoned. With the land best suited for agriculture already under cultivation (Young, 1999), agricultural expansion into marginal areas might buy time but would represent more of a delaying tactic than a sustainable strategy.

Innovation and technological advances, however, can coax greater production from less land and thereby offset resource constraints (Morrison, 2006; Tainter, 2006). Indeed, social and technological advances have repeatedly reduced the amount of land needed to feed a person (Table 1). Hunting and gather-
TABLE 1. HECTARES PER PERSON FOR DIFFERENT PLACES AND PERIODS THROUGH HISTORY

\begin{tabular}{lc}
\hline \hline Location and time period & Hectares/person \\
\hline Hunting-gathering & $20.00-100$ \\
Swidden & $2.00-10$ \\
Sedentary agriculture & $0.20-1.0$ \\
Mesopotamia & $0.50-1.50$ \\
Holland, 1800s & $0.25-0.33$ \\
Southern China, 1900s & 0.15 \\
Northern China, 1930s & 0.20 \\
Egypt, 1936 & 0.20 \\
Egypt, 1971 & 0.10 \\
China, 2000 & 0.11 \\
Indonesia, 2000 & 0.12 \\
Philippines, 2000 & 0.13 \\
Global average 1990 & 0.52 \\
Global average 2000 & 0.25 \\
\hline \multicolumn{2}{c}{ Note: Data compiled from Smil, 2001. } \\
\hline
\end{tabular}

ing societies required $20-100$ ha of land to support a person, whereas the shifting pattern of cultivation that characterized slash-and-burn agriculture took just 2-10 ha. The earliest sedentary floodplain-based agricultural societies used an estimated 0.5-1.5 ha of floodplain to feed a Mesopotamian. Today, it still takes $\sim 0.25$ ha to feed each person, with roughly six billion people and 1.5 billion hectares of cultivated land on the planet, although the world's most intensively farmed regions use just $0.1-0.2$ ha to support a person (Smil, 2001). Increasing the average global agricultural productivity to this level would support between 7.5 billion and 10 billion people. Yet by 2050 the amount of available cropland is projected to drop to $<0.1$ ha per person due to continued population growth and loss of cropland (USDA, 2004). Simply staying even in terms of food production will require major increases in per-hectare crop yields-increases that may not be achievable using industrial agriculture, despite human ingenuity.

Before 1950, most of the increase in global food production came from increasing the area under cultivation and improved husbandry. Since 1950, most of the increase has come from mechanization and growing use of chemical fertilizers. Dramatic intensification of agricultural methods during this green revolution is widely credited with averting a food crisis in the late twentieth century. Increased harvests were due to the development of high-yield "miracle" varieties of wheat and rice capable of producing two or three harvests a year, the increased use of chemical fertilizers, and massive investments in irrigation infrastructure in developing nations. The introduction of fertilizer-responsive rice and wheat increased crop yields by $>2 \%$ /yr between the 1950s and 1970s (Smil, 2001).

Since then, however, growth in crop yields has slowed to a virtual standstill. The great post-war increase in crop yields appears to be over. Wheat yields in the United States and Mexico are no longer increasing. Asian rice yields are starting to fall. Crop yields not only appear to have reached a technological plateau but are projected to fall in a warming climate (Peng et al., 2004). Thirty-year experiments on response to nitrogen fertilization at the International Rice Research Institute in the Philippines found that increasing nitrogen inputs were needed to counter declining soil fertility and maintain crop yields (Cassman et al., 1995). Nonetheless, over the coming decades, further annual increases of $1 \%$ to $1.5 \%$ are needed to 


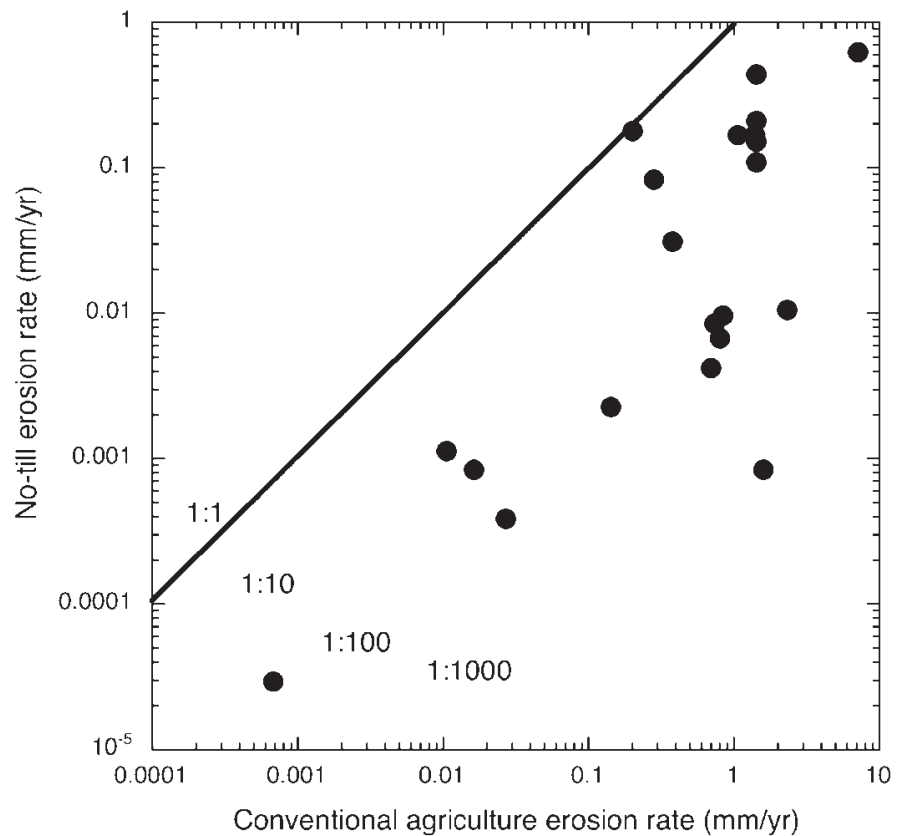

Figure 4. Erosion rates under no-till agricultural practices versus erosion rates under conventional agriculture on comparable terrain (see Montgomery, 2007b, for compiled data and sources).

meet projected demand for wheat, rice, and maize (Cassman, 1999). It is getting harder just to stay even, let alone increase crop yields.

Still, in the second half of the twentieth century, food production did double in great part due to a sevenfold increase in nitrogen fertilization and a three-and-a-half-fold increase in phosphorus fertilization (Tilman, 1999). But repeating this story seems rather unlikely because even tripling fertilizer applications won't help if plants cannot use the additional nitrogen and phosphorus. Crops already do not take up much of the nitrogen in the fertilizers farmers apply today-as shown by the vast hypoxic zone in the Gulf of Mexico created by the nitrogen-laden discharge from agricultural fields in the Mississippi River Basin (Turner and Rabalais, 2003). Even if we could, it might not do all that much good to dump more fertilizers on our fields.

\section{NO-TILL AND ORGANIC AGRICULTURE-THE NEXT REVOLUTION?}

Agriculture has experienced several revolutions in historical times and, much like mechanization did a century ago, changes in farming practices are once again transforming agriculture as farmers increasingly abandon the plow in favor of long-shunned no-till methods. Could the growing adoption of no-till and organic methods foster a new agricultural revolution based on soil conservation and soil ecology rather than soil chemistry? The typical arguments offered for why organic agriculture cannot feed the world have been blunted by recent studies showing that organic farming can produce both crop yields (Phillips et al., 1980; Blevins et al., 1998) and profits (Pimentel et al., 2005) comparable to conventional methods. Although no-till and organic methods may not be as productive and competitive in all situations, substantial expansion of both could happen without sacrificing either yields or profits.

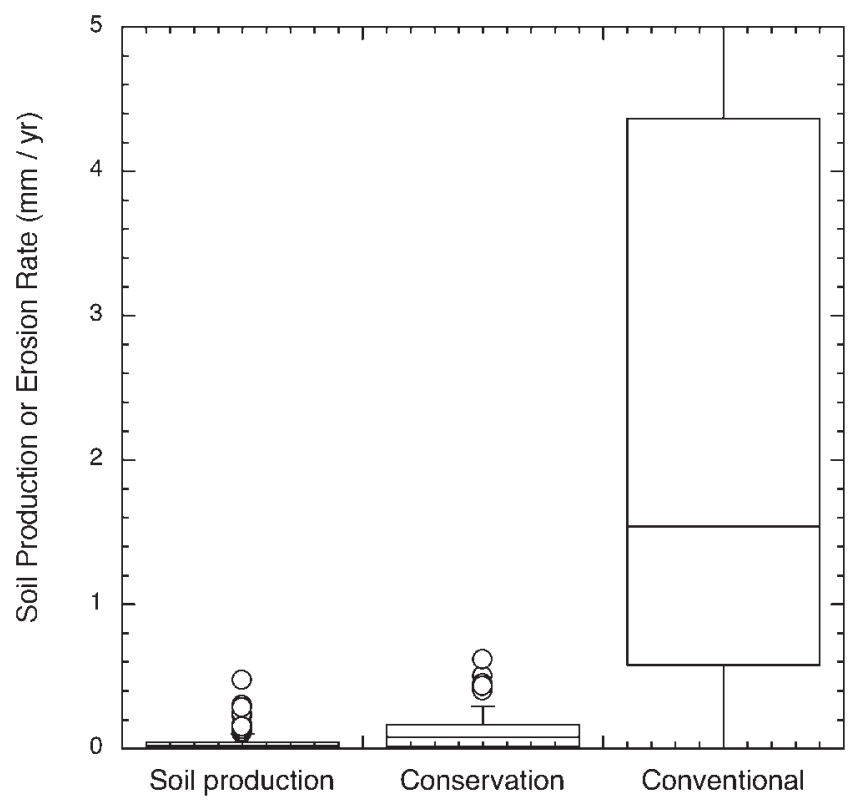

Figure 5. Box and whisker plots of soil production rates and rates of erosion under conservation agriculture and conventional agriculture. Boxes defined as median (line) \pm inner quartile, and whiskers defined as upper or lower quartile \pm 1.5 times the inner quartile distance (i.e., upper quartile less the lower quartile); circles mark outliers outside range of the whiskers. See Montgomery, 2007b, for compiled data and sources.

Instead of using a plow to turn the soil and open the ground, no-till farmers push seeds down through the organic matter from prior crops, minimizing direct disturbance of the soil. Leaving crop residue at the ground surface instead of plowing it under allows it to act as mulch, helping to retain moisture and leaving the soil less vulnerable to erosive rainfall and runoff. Consequently, no-till farming can greatly reduce soil erosion (Fig. 4) and even bring erosion rates close to soil production rates (Fig. 5). In addition to dramatically reducing soil loss, no-till methods can improve soil health and reduce costly energy inputs (Lal, 1976; Edwards et al., 1992; Ismail et al., 1994; Karlen et al., 1994).

Indeed, the attraction of such techniques will likely grow in the coming decades along with the cost of fossil fuels used to make chemical fertilizers and power the machinery needed to work large-scale mechanized farms. At the same time, local food production will become increasingly attractive in a world of higher transportation costs. Half the world's population now lives in cities where labor-intensive, low-tech urban farming techniques could dramatically contribute to ending hunger.

Despite the attraction of no-till and organic methods, challenging obstacles remain to their adoption-no-till methods are practiced on just $6 \%$ of global cropland (Lal, 2007). They can also be seen as somewhat conflicting, as leaving crop residues on the ground can foster weeds and attract pests, which can force some farmers to choose between soil-conserving no-till practices and environmentally detrimental herbicide and pesticide use. In addition, no-till methods work less well in cold and damp climates and are best suited for well-drained sandy 
and silty soils. Moreover, a key constraint on adoption of no-till methods in developing countries is that the biomass left on the fields under no-till practices is more valuable as cooking fuel (Lal, 2007).

Yet, rebuilding soil organic matter could provide one of the few simple, profitable ways to fend off global warming. When soil is plowed and exposed to the atmosphere, oxidation of organic matter releases carbon dioxide gas. A third of the total carbon dioxide buildup in the atmosphere since the industrial revolution has come from degradation of soil organic matter as hundreds of millions of acres of virgin land were plowed up in the late nineteenth and early twentieth centuries (Stuiver, 1978). No-till farming can reverse this process by stirring crop residues back into the soil surface, gradually increasing soil organic matter-as much as tripling soil carbon content in $<15$ $\mathrm{yr}$ in some studies. Conversion of all the world's croplands to no-till farming could sequester $1 \mathrm{Pg} \mathrm{C} \mathrm{yr}^{-1}$ (Pacala and Socola, 2004) while simultaneously rebuilding soil fertility. Increasing the organic matter content of agricultural soils could play a significant role in efforts to reduce the pace of global warming.

Like many environmental problems that become harder to address the longer they are neglected, soil erosion threatens to undermine the foundation of civilization over time scales longer than social institutions last. Irreplaceable over human time scales, soil is an awkward hybrid-an essential resource renewable only at a glacial pace. But unlike oil, there is no conceivable alternative for soil. Recent proposals to increasingly rely on conventionally grown corn and sugar cane to supply biofuels risk trading a system based on mining oil for one rooted in mining soil. Consequently, geoscientists will prove instrumental in establishing, evaluating, and implementing sustainable agricultural practices.

Indeed, as society grapples with agricultural issues in a post-petroleum world, geoscientists will have as great-and as fundamental - a role to play as do genetic and agricultural engineers. Sustainable agriculture will require adapting farming techniques to the land, and fertile soils are complex systems well-suited to study in the interdisciplinary perspective common amongst geoscientists. Although Leonardo da Vinci's insightful observation that "we know more about the celestial bodies than the soil underfoot" may no longer be literally true, further understanding of soil formation and erosion would help tailor agriculture to the land. Foremost among these are developing increased understanding of the controls on rates of weathering and soil production and on erosion under different agricultural techniques. In addition, the role of microbial life in establishing and maintaining soil fertility is becoming increasingly recognized as a research area critical for evaluating both conventional and alternative agricultural practices. The geosciences in general, and pedology, geobiology, hydrology, and geomorphology in particular, have key roles to play in defining, understanding, and implementing a path to feeding the world in the coming centuries.

For all the attention focused on global warming, the end of the oil era, and loss of biodiversity, there is a danger that society may neglect the most basic environmental change sweeping the planet. Even though it is hard to notice in a single lifetime, Earth's continents are losing their prime agricultural soils in a process that, if sustained, will eventually undermine civilization. Bringing soil erosion rates back into line with soil production rates could provide the basis for sustaining the soil-whether on industrial or organic farms. And adapting agricultural methods to the land could use agroecology to improve the soil even as it is worked to produce food. Still, we would be well served to recognize that the history of soil loss and degradation in past societies reveals that, paradoxically, sometimes the things that happen slowly are the most difficult to stop.

\section{ACKNOWLEDGMENTS}

I thank Kyle Nichols, Arun Heimsath, Dave Favis-Mortlock, and Gerry Ross for reviews and comments that greatly improved a draft manuscript.

\section{REFERENCES CITED}

Beach, T., 1998, Soil catenas, tropical deforestation, and ancient and contemporary soil erosion in the Petén, Guatemala: Physical Geography, v. 19, p. 378-404.

Beach, T., Dunning, N., Luzzadder-Beach, S., Cook, D.E., and Lohse, J., 2006, Impacts of the ancient Maya on soils and soil erosion in the central Maya Lowlands: CATENA, v. 65, p. 166-178, doi: 10.1016/j.catena.2005.11.007.

Blevins, R.L., Lal, R., Doran, J.W., Langdale, G.W., and Frye, W.W., 1998, Conservation tillage for erosion control and soil quality, in Pierce, F.J., and Frye, W.W., eds., Advances in Soil and Water Conservation: Chelsea, Michigan, Ann Arbor Press, p. 51-68.

Bridges, E.M., and Oldeman, L.R., 1999, Global assessment of human-induced soil degradation: Arid Soil Research and Rehabilitation, v. 13, p. 319-324, doi: 10.1080/089030699263212.

Brink, R.A., Densmore, J.W., and Hill, G.A., 1977, Soil deterioration and the growing world demand for food: Science, v. 197, p. 625-630, doi: 10.1126/ science.197.4304.625.

Brown, L.R., 1981, World population growth, soil erosion, and food security: Science, v. 214 , p. 995-1002, doi: 10.1126/science.7302578.

Cassman, K.G., 1999, Ecological intensification of cereal production systems: Yield potential, soil quality, and precision agriculture: Proceedings of the National Academy of Sciences of the United States of America, v. 96, p. 5952-5959, doi: 10.1073/pnas.96.11.5952.

Cassman, K.G., De Datta, S.K., Olk, D.C., Alcantara, J., Samson, M., Descalsota, J., and Dizon, M., 1995, Yield decline and the nitrogen economy of long-term experiments on continuous, irrigated rice systems in the tropics, in Lal, R., and Stewart, B.A., eds., Soil Management: Experimental Basis for Sustainability and Environmental Quality: Boca Raton, Florida, Lewis Publishers, p. 181-222.

Dale, T., and Carter, V.G., 1955, Topsoil and Civilization: Norman, University of Oklahoma Press, $270 \mathrm{p}$.

Edwards, J.H., Wood, C.W., Thurlow, D.L., and Ruf, M.E., 1992, Tillage and crop rotation effects on fertility status of a Hapludalf soil: Soil Science Society of America Journal, v. 56, p. 1577-1852.

Heimsath, A.M., Dietrich, W.E., Nishiizumi, K., and Finkel, R.C., 1997, The soil production function and landscape equilibrium: Nature, v. 388, p. 358-361, doi: $10.1038 / 41056$.

Heimsath, A.M., Chappell, J., Dietrich, W.E., Nishiizumi, K., and Finkel, R.C., 2000, Soil production on a retreating escarpment in southeastern Australia: Geology, v. 28, p. 787-790, doi: 10.1130/0091-7613(2000)28<787: SPOARE $>2.0 . \mathrm{CO} ; 2$

Hillel, D., 1991, Out of the Earth: Civilization and the Life of the Soil: Berkeley, University of California Press, $321 \mathrm{p}$.

Ismail, I., Blevins, R.L., and Frye, W.W., 1994, Long-term no-tillage effects on soil properties and continuous corn yields: Soil Science Society of America Journal, v. 58, p. 193-198.

Karlen, D.L., Wollenhaupt, N.C., Erback, D.C., Berry, E.C., Swan, J.B., Each, N.S., and Jordahl, J.L., 1994, Long-term tillage effects on soil quality: Soil and Tillage Research, v. 32, p. 313-327, doi: 10.1016/0167-1987(94)00427-G.

Kirch, P.V., 1996, Late Holocene human-induced modifications to a central Polynesian island ecosystem: Proceedings of the National Academy of Sciences of the United States of America, v. 93, p. 5296-5300, doi: 10.1073/ pnas.93.11.5296

Kirch, P.V., 1997, Microcosmic histories: Island perspectives on "global" change: American Anthropologist, v. 99, no. 1, p. 30-42, doi: 10.1525/aa.1997.99.1.30.

Lal, R., 1976, No-tillage effects on soil properties under different crops in western Nigeria: Soil Science Society of America Journal, v. 40, p. 762-768.

Lal, R., 2007, Constraints to adopting no-till farming in developing countries: Soil and Tillage Research, v. 94, p. 1-3, doi: 10.1016/j.still.2007.02.002.

Larson, W.E., Pierce, F.J., and Dowby, R.H., 1983, The threat of soil erosion to long-term crop production: Science, v. 219, p. 458-465, doi: 10.1126/ science.219.4584.458.

Montgomery, D.R., 2007a, Dirt: The Erosion of Civilizations: Berkeley, University of California Press, 295 p. 
Montgomery, D.R., 2007b, Soil erosion and agricultural sustainability: Proceedings of the National Academy of Sciences of the United States of America , v. 104 p. $13,268-13,272$

Morrison, K.D., 2006, Failure and how to avoid it: Nature, v. 440, p. 752-754, doi $10.1038 / 440752$ a.

Osterman, D.A., and Hicks, T.L., 1988, Highly erodible land: Farmer perceptions versus actual measurements: Journal of Soil and Water Conservation, v. 43, p. 177-182.

Pacala, S., and Socola, R., 2004, Stabilization wedges: solving the climate problem for the next 50 years with current technologies: Science, v. 305, p. 968-972, doi: $10.1126 /$ science. 1100103.

Peng, S., Huang, J., Sheehy, J.E., Laza, R.C., Visperas, R.M., Zhong, X., Centeno, G.S. Khush, G.S., and Cassman, K.G., 2004, Rice yields decline with higher night temperature from global warming: Proceedings of the National Academy of Sciences of the United States of America, v. 101, p. 9971-9975, doi: 10.1073/ pnas.0403720101

Phillips, R.E., Blevins, R.L., Thomas, G.W., Frye, W.W., and Phillips, S.H., 1980, No-tillage agriculture: Science, v. 208, p. 1108-1113, doi: 10.1126/ science.208.4448.1108.

Pimentel, D., Hepperly, P., Hanson, J., Douds, D., and Seidel, R., 2005, Environmental, energetic, and economic comparisons of organic and conventional farming systems: Bioscience, v. 55, p. 573-582, doi: 10.1641/0006-3568(2005)055[0573: EEAECO]2.0.CO;2.

Pope, K.O., and van Andel, T.H., 1984, Late Quaternary alluviation and soil formation in the Southern Argolid: Its history, causes and archaeological implications: Journal of Archaeological Science, v. 11, p. 281-306, doi: 10.1016/03054403(84)90012-8.

Runnels, C.N., 1995, Environmental degradation in Ancient Greece: Scientific American, v. 272, p. 96-99.

Ruttan, V.W., 1999, The transition to agricultural sustainability: Proceedings of the National Academy of Sciences of the United States of America, v. 96, p. 59605967, doi: 10.1073/pnas.96.11.5960.

Smil, V., 2001, Enriching the Earth: Fritz Haber, Carl Bosch, and the Transformation of World Food Production: Cambridge, The MIT Press, 338 p.

Stuiver, M., 1978, Atmospheric carbon dioxide and carbon reservoir changes: Reduction in terrestrial carbon reservoirs since 1850 has resulted in atmo- spheric carbon dioxide increases: Science, v. 199, p. 253-258, doi: 10.1126/ science.199.4326.253.

Tainter, J.A., 2006, Archaeology of overshoot and collapse: Annual Review of Anthropology, v. 35, p. 59-74, doi: 10.1146/annurev. anthro.35.081705.123136.

Tilman, D., 1999, Global environmental impacts of agricultural expansion: The need for sustainable and efficient practices: Proceedings of the National Academy of Sciences of the United States of America, v. 96, p. 5995-6000, doi: 10.1073/ pnas.96.11.5995.

Tilman, D., Fargione, J., Wolff, B., D'Antonio, C., Dobson, A., Howarth, R., Schindler, D., Schlesinger, W.H., Simberloff, D., and Swackhamer, D., 2001, Forecasting agriculturally driven global environmental change: Science, v. 292, p. 281284, doi: 10.1126/science 1057544.

Troeh, F.R., Hobbs, J.A., and Donahue, R.L., 1999, Soil and Water Conservation: Upper Saddle River, New Jersey, Prentice Hall, 600 p.

Turner, R.E., and Rabalais, N.N., 2003, Linking landscape and water quality in the Mississippi River basin for 200 years: Bioscience, v. 53, p. 563-572, doi: 10.1641/0006-3568(2003)053 [0563:LLAWQI]2.0.CO;2.

U.S. Department of Agriculture (USDA), Production, supply, and distribution: USDA electronic database, www.fas.usda.gov/psd, updated 13 August 2004

van Andel, T.H., Zangger, E., and Demitrack, A., 1990, Land use and soil erosion in prehistoric and historical Greece: Journal of Field Archaeology, v. 17, p. 379396, doi: 10.2307/530002.

Wakatsuki, $T$, and Rasyidin, A, 1992 Rates of weathering and soil formation: Geoderma, v. 52, p. 251-263, doi: 10.1016/0016-7061(92)90040-E.

Wilkinson, B.H., and McElroy, B.J., 2007, The impact of humans on continental erosion and sedimentation: Geological Society of America Bulletin, v. 119, p. 140-156, doi: 10.1130/B25899.1.

Young, A., 1999, Is there really spare land? A critique of estimates of available cultivable land in developing countries: Environment, Development and Sustainability, v. 1, p. 3-18, doi: 10.1023/A:1010055012699.

Manuscript received 29 March 2007; manuscript accepted 10 July 2007. 3

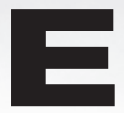

\section{Dirt}

The Erosion of Civilizations BY DAVID R. MONTGOMERY

"A compelling study on soil: why we need it, how we have used and abused it, how we can protect it, and what happens when we let it slip through our fingers."

"Insightfully chronicles the rise of agricultural technology and concomitant fall of soil depth just about everywhere in the world, from prehistoric to modern times.... The book raises a critical concern."-Nature $\$ 24.95$ hardcover

\section{-New Scientist}

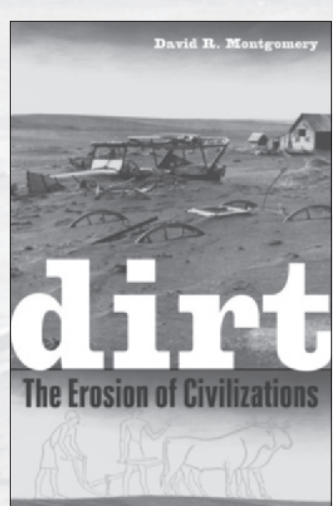

Earth under Fire

How Global Warming Is Changing the World

BY GARY BRAASCH Afterword by Bill McKibben

"Braasch's stories and photographs of how climate change is unraveling ecosystems and human lives make real and vivid what for too many remains speculative and abstract. Each deeply researched story becomes a memorable character in a rapidly unfolding drama that threatens to engulf us all."

\section{-Amory B. Lovins, Chairman and} Chief Scientist, Rocky Mountain

$\$ 34.95$ hardcover
Institute, Inc.

\section{Introduction to the Geology of Southern California and Its Native Plants}

BY CLARENCE A. HALL, JR.

An up-to-date, authoritative, and accessible resource for anyone interested in southern California's geology and native plants. Covering an extensive area, north from San Diego to Yosemite and east to the Mojave and Colorado deserts, its unique, compre hensive approach brings together for the first time the basic principles of geology, the story of plate tectonics, in-depth discussion of the geology of many specific locales within the region, and information on identifying southern California's native plants. $\$ 75.00$ hardcover 